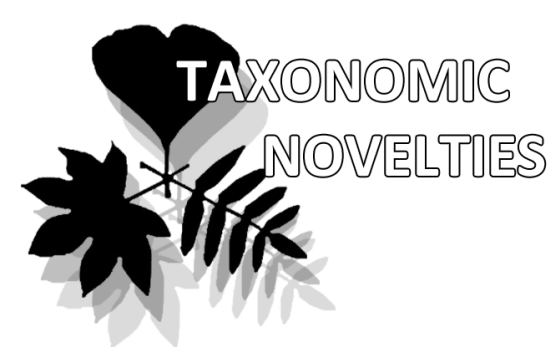

\title{
Wielandiella villosa comb. nov. from the Middle Jurassic of Daohugou, China: More Evidence for Divaricate Plant Architecture in Williamsoniceae
}

\author{
Christian Pott ${ }^{1}$, Wang Xiaoli ${ }^{2} \&$ Zheng Xiaoting ${ }^{2,3}$
}

Christian Pott $^{1 *}$

e-mail: christian.pott@nrm.se

Wang Xiaoli ${ }^{2}$

e-mail: wangxiaoli@lyu.edu.cn

Zheng Xiaoting ${ }^{2,3}$

e-mail: zhengxiaoting@lyu.edu.cn

${ }^{1}$ Swedish Museum of Natural History, Department of Palaeobiology, Box 50007, 10405 Stockholm, Sweden

${ }^{2}$ Linyi University, Institute of Geology and Paleontology, Linyi, Shandong, 276005, China

${ }^{3}$ Shandong Tianyu Museum of Natural History, Pingyi, Shandong, 273300, China

* corresponding author

Manuscript received: 06.08.2015

Review completed: 02.09.2015

Accepted for publication: 30.09 .2015

Published online: 23.10.2015

\begin{abstract}
A B S T R A C T
Recently discovered fossils yielding branched axes with attached foliage are described from the Middle Jurassic Daohugou beds, Inner Mongolia, China. The leaves of the plant were earlier described as isolated and disarticulated foliage and assigned to Anomozamites villosus; the plant architecture, however, necessitates the re-assignment of the fossils under study to $W$ ielandiella, a bennettitalean wholeplant fossil taxon that includes stems, leaves and unisexual ovuliferous reproductive structures. Wielandiella villosa is the second known species attributable to Wielandiella and extends the taxon's range from the Rhaetian into the Middle Jurassic. Wielandiella villosa is interpreted to encompass specialised shrubs that are regarded to have thrived in swampy settings but also potentially extended to other lowland habitats, especially where conditions of physiological drought prevailed; conditions that, in modern vegetation, are considered to favour the development of divaricate plant growth forms. The foliage and reproductive organs of these medium-sized shrubs would have been of suitable size for ground-based animals to browse, potentially also stimulating a divaricate growth form in Wielandiella villosa. The ecological pressures promoting indumentum development and the protruding hairs on the leaves of $W$ ielandiella villosa are interpreted as predominantly an adaptation for passive defence against herbivores rather than xeromorphic features. The latter add to ongoing investigations of the depositional setting of the fossils in order to unravel the plant's habitat and micro-climate at Daohugou. K e y w o r d s : Bennettitales, Anomozamites, Middle Jurassic, Inner Mongolia, Daohugou Biota, whole-plant fossil taxon
\end{abstract}

\section{P E 3 Ю M E}

Потт Х., Ван С., Чжен С. Wielandiella villosa comb. nov. из среднеюрских отможений Ааохугоу, Внутренная Монголия, Китай: Аополнительное подтвержАение ветвистой структуры побегов преАставителей Williamsoniceae. Недавно обнаруженные окаменелости побегов, несущих разветвленные оси с прикрепленными Аистьями, описаны из среднеюрских отложений Ааохугоу, Внутренняя Монголия, Китай. По Аистьям растение идентифицировано как Anomozamites villosus, ранее описанный по изолированным и расчлененным Аистьям. Архитектура растения однако требует отнесения фоссилий к Wielandiella, описанному на основе целого экземпляра таксона беннеттита, который включает стебли, Аистья и однополые семенные репродуктивные структуры. Wielandiella villosa - второй вил из ныне известных в роде, что расширяет временной диапазон существования таксона от рэта до средней юры. Реконструированное растение сравнивается с Wielandiella angustifolia из европейского рэта, обсуждаются его экологические характеристики, которые Аают представление о жизненном цикле и адаптациях к факторам среды, а также информацию об особенностях осадконакопления в Ааохугоу в существовавших климатических условиях.

К $\mathbf{\Lambda}$ ю че в ы е с $\mathbf{\Lambda} о$ в а : Bennettitales, Anomozamites, средний отАел юрского периоАа, Внутренняя Монголия, биота Ааохугоу, ископаемый таксон на основе целого растения

Переведено редколмегией

\section{INTRODUCTION}

The Mesozoic biotas of northern China, including the Middle Jurassic Daohugou Biota, constitute exceptionally preserved fossil ecosystems, the comprehensive studies of which, carried out during the last few decades, have revolutionised our understanding of animal and plant evolution (see, e.g., Chang et al. 2003). The discoveries of articulated dinosaurs in these strata are some of the most notable findings (e.g.,
Sullivan et al. 2014), but the deposits have yielded an array of other vertebrate, invertebrate and plant remains that provide evidence of a number of trophic levels and novel adaptations to specific habitats and selective environmental pressures. The record of vertebrate and invertebrate fossils from the Daohugou Biota has significantly increased during the last decade (e.g., Tan \& Ren 2002, Huang et al. 2006, Wang et al. 2006, Gao et al. 2009, Zheng et al. 2009, Sullivan et al. 2014), 
revealing a remarkably diverse and rich late Middle Jurassic fauna, whereas the associated plant fossils have received little attention (e.g., Zheng et al. 2003, Pott et al. 2012b). Consequently, the plants provide a largely unexploited source of data for the reconstruction of the palaeo-vegetation, habitats or plant-animal interactions in the Daohugou ecosystem.

During an ongoing study of the Middle Jurassic Daohugou flora by the authors, two fossils were identified yielding plant components that notably resemble Wielandiella Nath. Wielandiella encompasses bennettitalean plants attributed to Williamsoniaceae. These plants differ from other gymnosperms by their growth habit and plant architecture, which recently has been classified as divaricate (Pott \& McLoughlin 2014). Wielandiella is, to date, monospecific, comprising Wielandiella angustifolia Nath. reported from the Rhaetian (uppermost Triassic) of Scania, southern Sweden, and Jameson Land, eastern Greenland (Nathorst 1909, Harris 1932, Pott 2014) as well as Franconia, southern Germany (CP, personal observation, August 2015). The plant was initially restored a century ago by Nathorst $(1888,1909)$ based on the reassembly of isolated fossils; a detailed analysis, careful re-interpretation and restoration of the plant was recently published by Pott (2014), who for the first time discussed the plant architecture and growth habit in relation to ecological pressures as well as reproductive strategies of the plant.

The exceptional condition of the newly discovered and well-preserved fossils from Daohugou described herein provides additional insights into the growth habit and ecology of Wielandiella as they constitute branched axes with attached foliage. The foliage, previously found isolated and disarticulated, was recently described as Anomozamites villosus C. Pott, McLoughlin, S.Q. Wu et E.M. Friis (Pott et al. 2012b) from the same locality. The intriguing presence of a shaggy indumentum on the leaf surface and long and stiff hairs along the rachis in combination with distinctive damage to the leaves presumably caused by herbivorous arthropods prompted Pott et al. (2012b) to suggest various ecological interpretations without knowing the exact architecture of the plants.

Here, we describe new fossils that yield characters necessitating the emendation of Anomozamites villosus and its reassignment to Wielandiella. The plant architecture of Williamsoniaceae is unique amongst gymnosperms, not only with regard to its divaricate growth form, but also when correlated with the architectural tree models described and summarised by Hallé et al. (1978). We briefly review the plant architecture, growth habit and possible ecological strategies of Wielandiella.

\section{MATERIAL AND METHODS}

The studied fossils were obtained in 2007 from local farmers in the area of the Daohugou Village, Shantou Township, Ningcheng County, Inner Mongolia, PR China (41ํำ $19^{\prime} 11^{\prime \prime}$ N, $119^{\circ} 14^{\prime} 07^{\prime \prime}$ E; Fig. 1), and acquired by Zheng Xiaoting for the Shandong Tianyu Museum of Natural History, Pingyi, PR China. They are hosted in the palaeobotanical collections of the museum under accession numbers 47-64 and 47-944. Both fossils consist of part and counterpart. Seven additional fossils were included in this study that represent bennettitalean reproductive structures.
These are stored in the same collection under accession numbers 47-954, 47-955, 47-956, 47-958, 47-959, 47-960 and 47-961.

The fossils were photographed with Panasonic Lumix DMC-TZ41 and Nikon D90 system cameras using variable (oblique) illumination. Polarisation filters in front of the camera lens and the lamps were used to enhance contrast, colour intensity and accentuate the fine details of the fossils. Specimen 47-64 was sealed in a display cabinet, which could not be opened. The fossil was, therefore, photographed through the glass cover of the cabinet; to avoid reflections and distortions, the glass surface was covered with water, to which a drop of dishwashing detergent was added to remove the surface tension of the water.

\section{GEOLOGICAL SETTING}

A $100-150 \mathrm{~m}$ thick sequence of greyish to whitish, very finely laminated silty claystones to $\mathrm{cm}$-thick fine to medium sandstones with repeated intercalations of $\mathrm{cm}$ - to $\mathrm{m}$-thick ash-fall tuffs, ignimbrites and tuffites constitute the Daohugou beds. The individual beds are laterally persistent within the exposures and generally normal-graded, a typical deposition pattern within low-energy lacustrine settings. The Daohugou beds are exposed along the boundaries of the provinces of Inner Mongolia, Hebei and Liaoning, and are thus located within the Jurassic-Cretaceous Ningcheng Basin. The fossiliferous succession at Daohugou is placed either into the upper Jiulongshan Formation (e.g., Ren et al. 2002, Gao \& Ren 2006) or into the lower Tiaojishan Formation (e.g., Liu et al. 2006). The precise age and stratigraphic position have been debated extensively (e.g., Gao \& Ren 2006, He et al. 2004, Wang et al. 2005), but the vast majority of results published thus far indicate a late Middle Jurassic age for the Daohugou Biota (Ren et al. 2002, Chang et al. 2003, Shen et al. 2003, Chen et al. 2004, Ji et al. 2004, Gao \& Ren 2006, Huang et al. 2006, Liu et

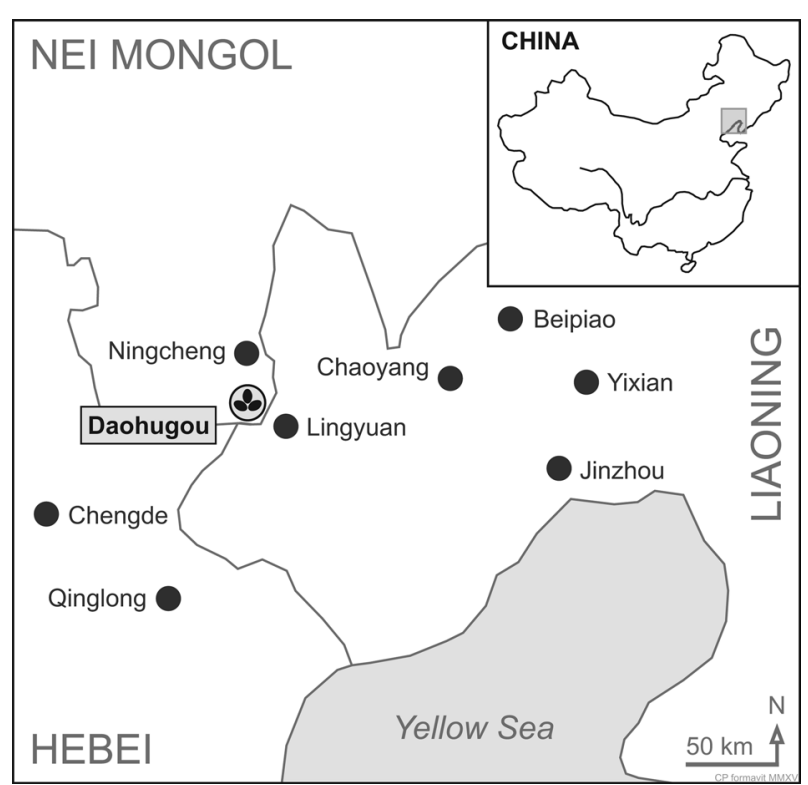

Figure 1 Map of mainland China, showing the position of Daohugou in Inner Mongolia, where the specimens under study have been obtained 
al. 2006, Zhang et al. 2008). The Daohugou assemblages probably correlate with the Middle Jurassic Yan-Liao Biota, indicated by a well-preserved diplostracan fauna (see also Huang et al. 2006).

\section{RESULTS}

\section{Wielandiella Nath. 1910 emend. C. Pott 2014}

Wielandiella was recently revised by Pott (2014) and the generic description has been emended after thorough analysis of all original material. However, the author was not able to unequivocally prove the attachment of the leaves due to lack of organic connection between foliage and any of the axes. In the restoration of the plant, Pott (2014) followed the classical interpretation of, e.g., Nathorst (1888, 1909) and other contemporary and later scholars, which was based on the most obvious positioning of the leaves on the axes and on additional supporting evidence (see Pott [2014] for further details). Based on the fossils presented here, the type and position of the attachment of the leaves can now be confirmed. It is also documented that persistent leaves are only present at the uppermost row of leaf scars at the tips of the youngest branches, and older leaves are shed as a whole leaving distinct leaf scars. This strategy is not unexpected (see, e.g., Pott et al. 2012a), but has not yet been documented for the genus.

\section{Wielandiella villosa (C. Pott, McLoughlin, S.Q. Wu et E.M. Friis) C. Pott comb. nov.}

Figs. 2-14.

Basionym. Anomozamites villosus, C. Pott, McLoughlin, S.Q. Wu et E.M. Friis 2012, Review of Palaeobotany and Palynology 169, p. 50.

Holotype. B0169B. Repository: Institute of Vertebrate Paleontology and Paleoanthropology (IVPP), Beijing, PR China (see Pott et al. 2012b).

Epitypes. 47-64, 47-944. Repository: Shandong Tianyu Museum of Natural History, Pingyi, PR China. Figured here on Figs. 2-14.

Type locality. Daohugou Village, Shantou Township, Ningcheng County, Inner Mongolia, PR China (4119’11”N, $119^{\circ} 14^{\prime} 07^{\prime \prime}$ E; Fig. 1).

Type stratum. Daohugou beds (lower Tiaojishan or upper Jiulongshan Formation), probably late Middle Jurassic (see Ji et al. 2004, Wang et al. 2005, Liu et al. 2006).

Emended diagnosis. Woody plants with predominantly sympodially branched (divaricate) axes with persistent leaf scars in restricted areas below branching points and at apical branch termini; petiolate leaves shed as a whole, present on apical branch portions only; persistent leaf scars rhombic, compressed in older stem portions; leaves imparipinnate, small, narrow oblong to oblanceolate in gross outline; lamina regularly segmented, lacking an apical leaflet; leaflets opposite to alternate and densely arranged, inserted laterally to the rachis at almost $90^{\circ}$, entirely free to the base, falcate to quadrate; leaflet apices bluntly rounded, bases slightly contracted; several fine veins entering the leaflets, bifurcating close to the rachis and then traversing the leaflet perpendicular to the rachis. Margins and abaxial side of the rachis densely covered with long, stiff hairs; abaxial leaflet surface densely covered with soft, shaggy hairs; dichasial inflorescence and plant architecture, main axis with reduced growth, terminating in a single reproductive structure, supported by a whorl of persistent sterile leaves (bracts).

Description. A considerable number of individual, detached and isolated leaves have been reported and illustrated in detail by Pott et al. (2012b). Therefore, we restrict the description here to the new specimens that provide details of branched and foliate axes.

Specimen 47-944 (Figs. 2-5) represents a $57.6 \mathrm{~mm}$ long and $3.5-4.0 \mathrm{~mm}$ wide axis that widens apically to a maximum width of $6.7 \mathrm{~mm}$. The naked portion of the axis below the widening bears longitudinal wrinkles, with the outer edges (c. $1 / 5$ of the axis' width on each side) offset or embossed. At the $15 \mathrm{~mm}$ long, expanded portion, the axis displays 12 rows of rhombic-elliptical leaf scars (up to 2.3 $\mathrm{mm} \times 1.5 \mathrm{~mm}$ wide; Figs. 2, 4). The uppermost row bears six petiolate leaves of the Anomozamites villosus-type (Fig. 3). The leaves conform to the description provided by Pott et al. (2012b) for isolated leaves from the same locality, and there is no doubt that the leaves are conspecific. They are narrow oblong to oblanceolate in general outline, regularly segmented into bluntly rounded but parallel-sided and oppositely to sub-oppositely arranged leaflets. Leaflets are inserted laterally to the axis, an apical leaflet is lacking. The leaves bear long and stiff hairs along their rachis on the abaxial surface. The longest leaf is $66.0 \mathrm{~mm}$ long and 22.1 $\mathrm{mm}$ wide at its widest portion.

Specimen 47-64 (Figs. 6-14) yields two branch increments. The naked central axis (5.2 mm wide) terminates in a developing flower or bud (Figs. 11, 13), producing two lateral branches ( 98.3 and $88.3 \mathrm{~mm}$ long, $4.6 \mathrm{~mm}$ wide; Figs 6-7) immediately below it. The expanded area below the branching is characterized by several rows of compressed rhombic leaf scars. The naked lateral branches are of the same appearance as in the other specimen (i.e. embossed margins, depressed central part), and are distally terminated by an area with rhombic leaf scars (Figs. 8, 12, 14), whose uppermost row gives rise to one whorl of five Anomozamites villosus-type leaves on each branch (Figs. 6-7). The longest preserved leaf portions are $63.1 \mathrm{~mm}$ long and $23.4 \mathrm{~mm}$ wide, and are of the same architecture, shape and constitution as those in the other specimen and those reported by Pott et al. (2012b). They show the same long and stiff hairs (Figs. 9-10) along the rachis and reveal indistinct shaggy hair cover on the abaxial surface of the leaflets. The leaves are interpreted as being inserted almost perpendicularly to the axes during life. Leaves that are preserved bent down and almost parallel to the axis, are most likely a result of senescence or distortion through transportation. The developing flower bud is $8.5 \mathrm{~mm}$ wide and $6.9 \mathrm{~mm}$ high (Fig. 13), acutely rounded and characterized by two rows of developing scale leaves probably enclosing the developing gynoecium. The preservation and storage of the fossil in a sealed glass cabinet did not allow for detailed examination of the flower bud. The counterpart yields a third axis produced at the branching point, whose preserved portion is $11 \mathrm{~mm}$ long (Fig. 11). 


\section{Ovulate cones}

Several ovulate cones (Figs. 15-21) have been obtained from the Daohugou beds, which are very similar in structure, architecture and composition to those reported from the Rhaetian of Scania and Jameson Land by Nathorst (1880, 1888, 1909), Harris (1932) and Pott (2014) as ovulate cones ('flowers') of Wielandiella angustifolia. The sole difference is that they are about $25 \%$ larger in all dimensions, but this also applies to the width of the sterile leaves of Wielandiella villosa (Pott et al. 2012b, Pott 2014). None of these ovulate cones has been found in organic connection with the fossils described above, but all slabs bearing ovulate cones also host portions of detached or isolated leaves of the Anomozamites villosus-type (Figs. 20-21), which is additional evidence that these organs are biologically linked.

The ovulate cones are spherical to ovoid in outline, and up to $36.5 \mathrm{~mm}$ long and $30.7 \mathrm{~mm}$ wide. They consist of a central, elongate, pyriform receptaculum that is $6.7 \mathrm{~mm}$ wide at its widest portion, surrounded by a $9-11 \mathrm{~mm}$ wide layer of undifferentiated rock matrix corresponding to the layer of interseminal and ovuliferous scales (Figs. 15-17), the apical region of which in one specimen yields some poorly preserved details of individual scales (Fig. 17). The receptaculum does not project through the mantle of scales and no corona is present (Fig. 17). Proximally, the point is visible, where the ovulate cone was attached to the axis ( $\varnothing$ $5-6 \mathrm{~mm}$ ) together with the insertion scars of the diverging scale leaves (Fig. 19). Seventeen to twenty lanceolate, 3.9$4.8 \mathrm{~mm}$ wide scale leaves encompass the gynoecium along its entire length, project above its apex, and touch at their tips. The scale leaves even show the characteristic wrinkles seen in Wielandiella angustifolia (Fig. 18; see Pott 2014).

\section{DISCUSSION}

\section{Assignment to Wielandiella and comparison with other species}

The two specimens are assigned to Wielandiella based on the characteristic branching pattern, the termination of the main axes by the production of a reproductive structure, and the Anomozamites-type foliage arranged in whorls at the apical ends of branches that leave characteristic leaf scars when abscised as a whole. In the presented specimens, the reproductive structure is not yet developed, but a structure that can be interpreted as a developing bud is present in the designated area. The ovulate cones described above are interpreted to represent more fully developed fertile organs of Wielandiella villosa.

The specimens described from the Rhaetian of Scania (Pott 2014) yield only axes with abscised leaves and matured (naked) gynoecia that already abscised their ovules (Nathorst 1888, 1909, Harris 1932, Pott 2014). The specimens from Jameson Land (Harris 1932, Pott 2014), in contrast, show a matured 'flower' terminating the main axis and inducing subtending branching, each of the branches later becoming main axes. Sterile foliage was always abscised in the specimens from both localities, which favored the interpretation that sterile foliage was always shed before maturity of the reproductive structures.
Wielandiella has previously been regarded monospecific with Wielandiella angustifolia the only species. When Nathorst (1909) introduced Wielandiella, he identified a second species, viz. Wielandiella punctata Nath., based on fragmentary remains, which he thought resembled 'flower' fragments of Wielandiella angustifolia. These fragments, however, were later assigned to a species of Hydropterangium T. Halle by Lundblad (1950) with affinities of pteridosperms and more closely associated with Ptilozamites Nath.; in addition, its cuticle does not warrant a bennettitalean affinity (Lundblad 1950, Pott 2014). Hydropterangium has been regarded as a potential microsporangiate organ of Wielandiella by Crane (1985). Due to contrasting evidence provided elsewhere, this is unjustified. In contrast, Pott (2014) compiled a number of conclusive arguments for another, yet unassigned, bennettitalean microsporangiate organ, viz. Bennettistemon bursigerum Harris, as the microsporangiate organ of Wielandiella although definitive assignment requires evidence in the form of organic connection.

Fiore (1935) described a very small 'strobilus' from the Hettangian ('Liassic') near Verona in Italy, and assigned it to Wielandiella angustifolia. The strobilus is $14 \mathrm{~mm}$ long and 6 $\mathrm{mm}$ in diameter, with a $4 \mathrm{~mm}$ long and $1.5 \mathrm{~mm}$ wide petiole and four to five bracts. The assignment to Wielandiella angustifolia was based mainly on the proportions of the reproductive structure, but Fiore (1935) also mentioned branch portions similar to those of Wielandiella angustifolia; vegetative foliage, however, was not found in association with the ovulate cone. The assignment cannot be verified as no figure was provided by Fiore (1935), but in our view, the ovulate cone is much too small to be a reproductive structure of Wielandiella angustifolia.

Wielandiella kryshtofovichii Pryn. has been described from an unidentified Lower Cretaceous stratum at Firsov Point, Vladivostok, Southern Primorye, Russian Federation, by Kryshtofovich \& Prynada (1932). Unfortunately, the description includes only pinnate leaves $(40-57 \mathrm{~mm}$ long, 27-28 mm wide) with short petioles and ovate leaflets. The apical leaflets are round-emarginate. All have parallel, slightly arcuate venation but veins reach the margin perpendicularly. Seven to nine veins were measured per $5 \mathrm{~mm}$. No axes and no reproductive structures were reported and, consequently, this species would need to be transferred to Anomozamites Schimp. (viz. Anomozamites kryshtofovichii), because Wielandiella characteristically includes axes and reproductive structures.

The foliage of Anomozamites haifanggouensis (T. Kimura, T. Ohana, L.M. Zhao et B.Y. Geng) Shao L. Zheng et L.J. Zhang (Zheng et al. 2003), reported from the Jiulongshan Formation at the Daohugou village (see Pott et al. 2012b), is superficially similar to that of Wielandiella villosa, but has been clearly distinguished from it by Pott et al. (2012b). The Anomozamites haifanggouensis plant was regarded to be architecturally organized in a similar manner as Wielandiella angustifolia by Zheng et al. (2003), but supporting evidence for this interpretation in the form of illustrations and photographs of any fossil has not been provided. The rather peculiar 'bracteoid small leaves' and 'microsporophylls' mentioned by the authors have also not been described convincingly 

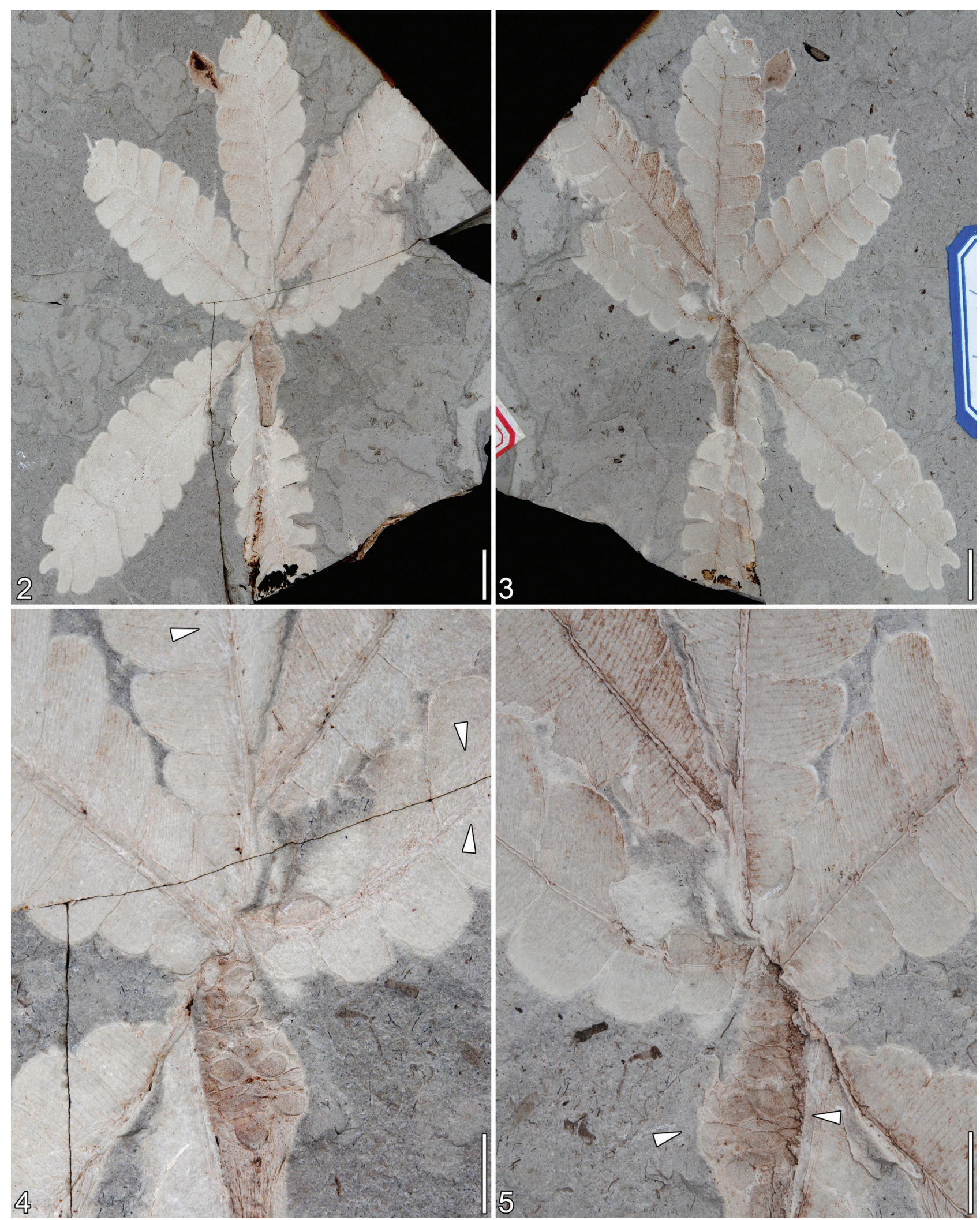

Figures 2-5 Wielandiella villosa comb. nov. from the Middle Jurassic of Daohugou, Inner Mongolia, PR China. Epitype, specimen 47-944, part and counterpart. Fig. 2. Subordinate branch with persistent leaf scars apically and six preserved Anomozamites villosus-leaves attached to the uppermost row of leaf scars. Fig. 3. Counterpart of specimen in Fig. 2. Fig. 4. Detail of Fig. 2, showing the leaf scars, the attachment of the leaves and stiff hairs along the rachis (arrowheads). Fig. 5. Detail of Fig. 3, showing leaf scars (arrowheads) and the attachment and venation of the leaves. Repository: Shandong Tianyu Museum of Natural History, Pingyi, PR China. Scale bars - 10 mm (Figs. 2, 3), 5 mm (Figs. 4, 5) 

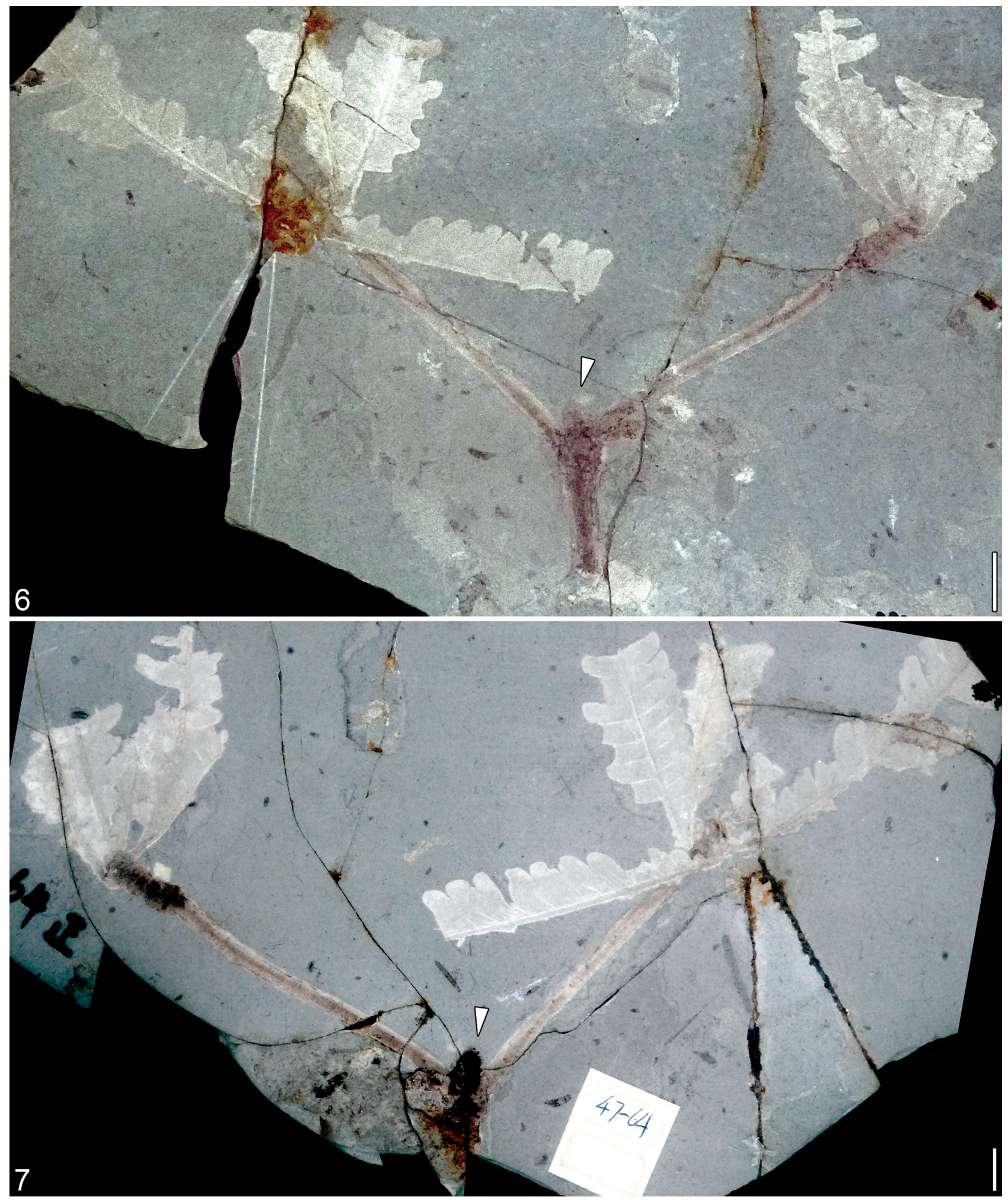

Figures 6-7 Wielandiella villosa comb. nov. from the Middle Jurassic of Daohugou, Inner Mongolia, PR China. Epitype, specimen 47-64, part and counterpart. The specimen shows two branch increments with the main axis terminated by a developing reproductive structure ('flower' bud, arrowheads); each subordinate branch is distally terminated by an area with rhombic leaf scars, whose uppermost row gives rise to one whorl of five Anomozamites villosus-type leaves on each branch. Repository: Shandong Tianyu Museum of Natural History, Pingyi, PR China. Scale bars $-10 \mathrm{~mm}$

enough to be regarded as microsporangiate organs (compare here with the original description of the fossils by Kimura et al. [1994]). Both leaf types could be regarded as two layers of bracts of the ovulate organs that opened for the reception of pollen as they resemble very much Cycadolepis Saporta scale leaves (Kimura et al. 1994, Harris 1969, Pott et al. 2010); the presence of pollen grains on the leaves can easily be explained by release through any pollination vector (wind/ animal), and is not a reliable indicator that the leaves or bracts were microsporangiate organs. 

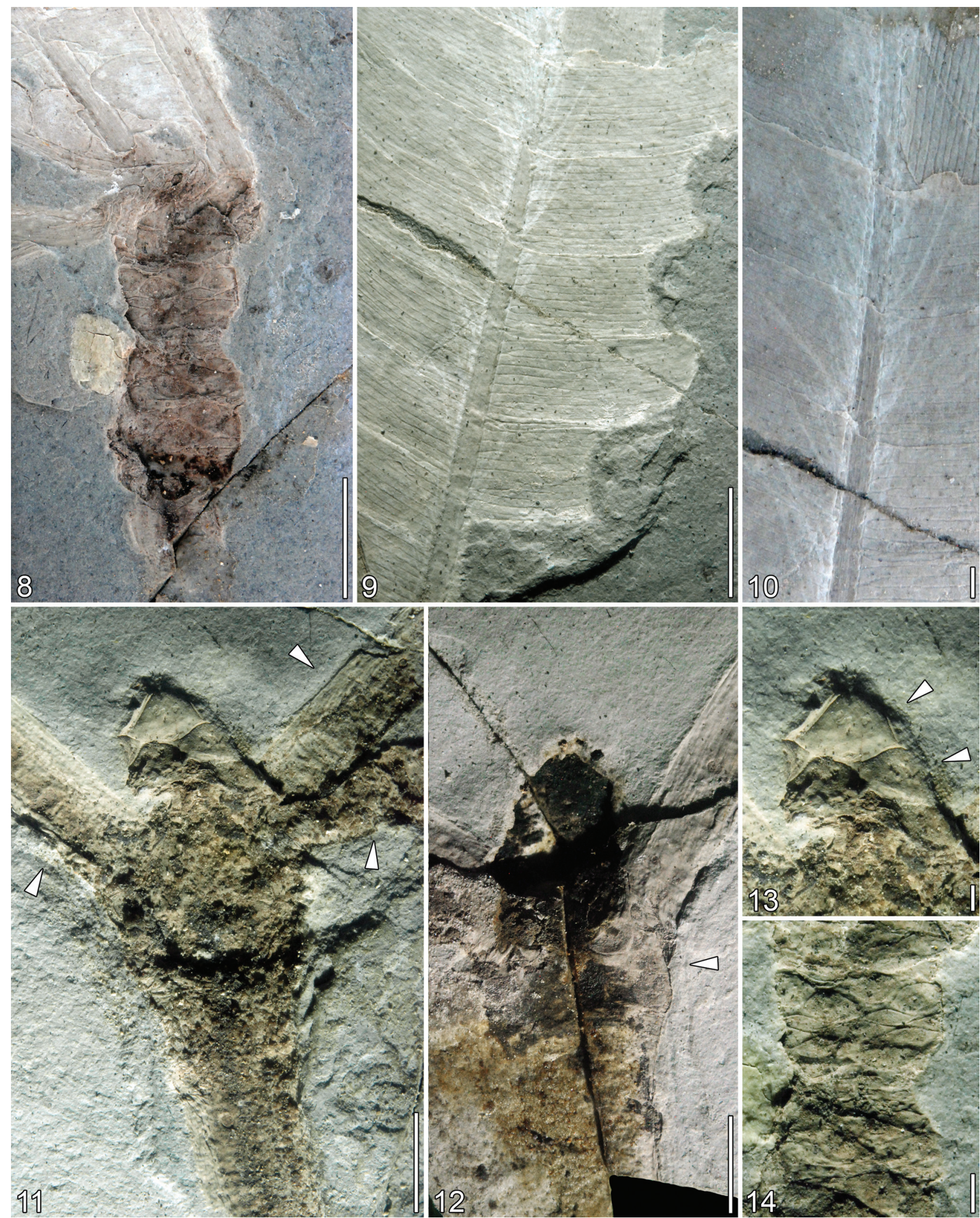

Figures 8-14 Wielandiella villosa comb. nov. from the Middle Jurassic of Daohugou, Inner Mongolia, PR China. Details of specimen 4764, part and counterpart. Fig. 8. Detail of the apical portion of a subordinate branch with the persistent leaf scars and bases of the leaves attached to the uppermost row of leaf scars. Fig. 9. Close-up of the central portion of a leaf depicting the venation and characteristic stiff hairs along the rachis. Fig. 10. Close-up of the rachis with the stiff hairs appearing whitish. Fig. 11. Detail of the branching area with the developing reproductive structure and three subordinate branches (arrowheads). Fig. 12. Same area of counterpart, showing the persistent leaf bases below the branching (arrowhead). Fig. 13. Close-up of the bud or developing reproductive structure with the initial bracts or scale leaves (arrowheads). Fig. 14. Details of the leaf scars at the apex of a subordinate branch. Repository: Shandong Tianyu Museum of Natural History, Pingyi, PR China. Scale bars - 10 mm (Figs. 8, 9), 5 mm (Figs. 11, 12), 1 mm (Figs. 10, 13, 14) 

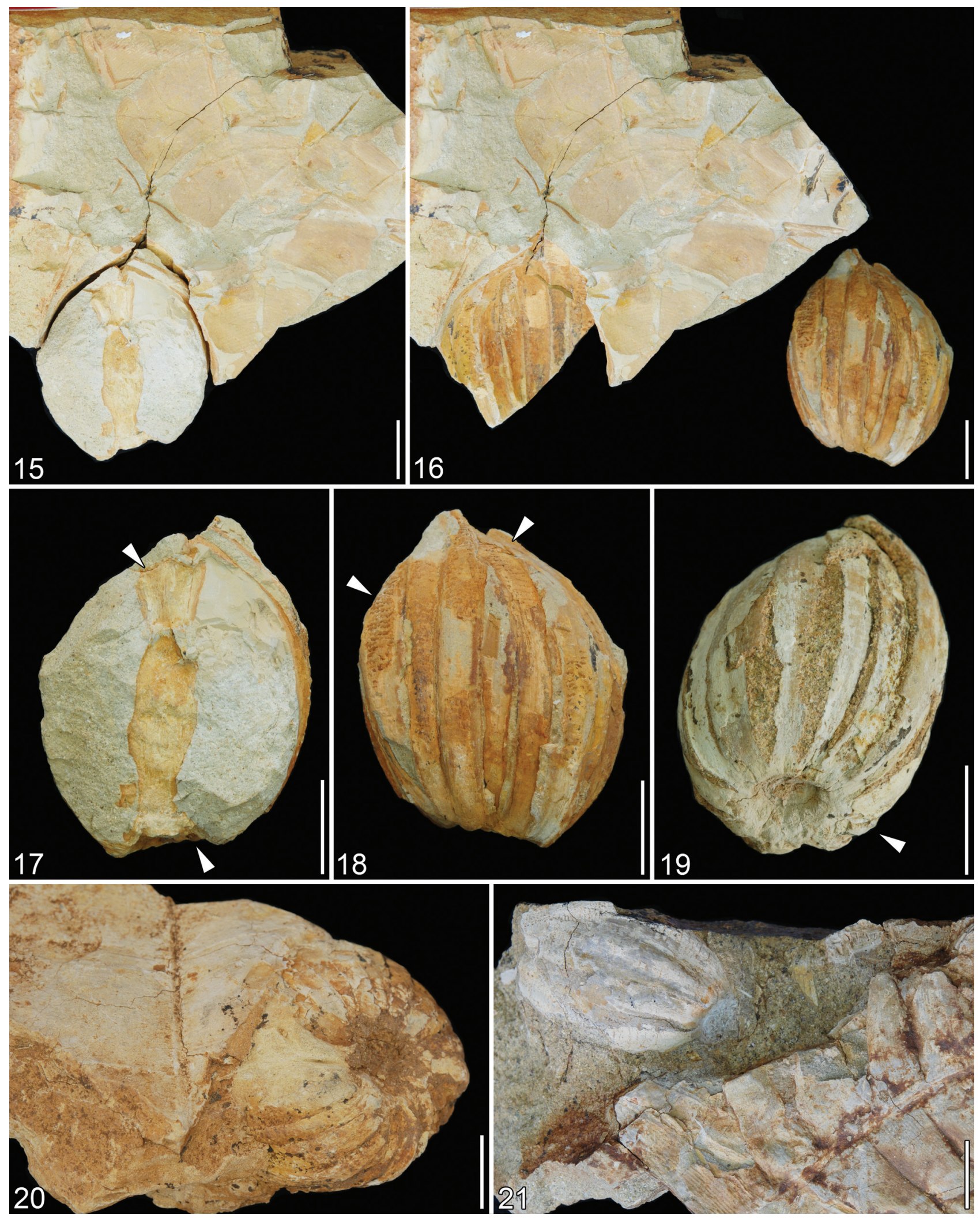

Figures 8-14 Ovulate cones, presumably of Wielandiella villosa comb. nov., from the Middle Jurassic of Daohugou, Inner Mongolia, PR China. Fig. 15. Specimen yielding an ovulate cone, cut in half and depicting its inner structure, and an Anomozamites-type leaf on the upper part of the specimen. Fig. 16. Same specimen as in Fig. 15 but with the ovulate cone removed depicting its impression and outer structure; note the slender bracts or scale leaves. Fig. 17. Isolated ovulate cone from Fig. 15, depicting its inner structure; note the attachment point (lower arrowhead), continuing into the receptacle, and the undifferentiated rock matrix corresponding to the laver of interseminal and ovulate scales, of which some details are visible in the apical portion (upper arrowhead). Fig. 18. Isolated ovulate cone from Fig. 15 showing the slender bracts with characteristic wrinkles (arrowheads). Fig. 19. Another ovulate cone of similar size with slender bracts and well-preserved attachment area with the insertion scars of the bracts (arrowhead). Fig. 20. Specimen with an ovulate cone and an Anomozamites-type leaf to the left. Fig. 21. Specimen with an ovulate cone and an Anomozamites-type leaf to the right. Specimens: 47-960 (Fig. 15-18), 47-958 (Fig. 19), 47-954 (Fig. 20), 47-955 (Fig. 21). Repository: Shandong Tianyu Museum of Natural History, Pingyi, PR China. Scale bars - 10 mm 


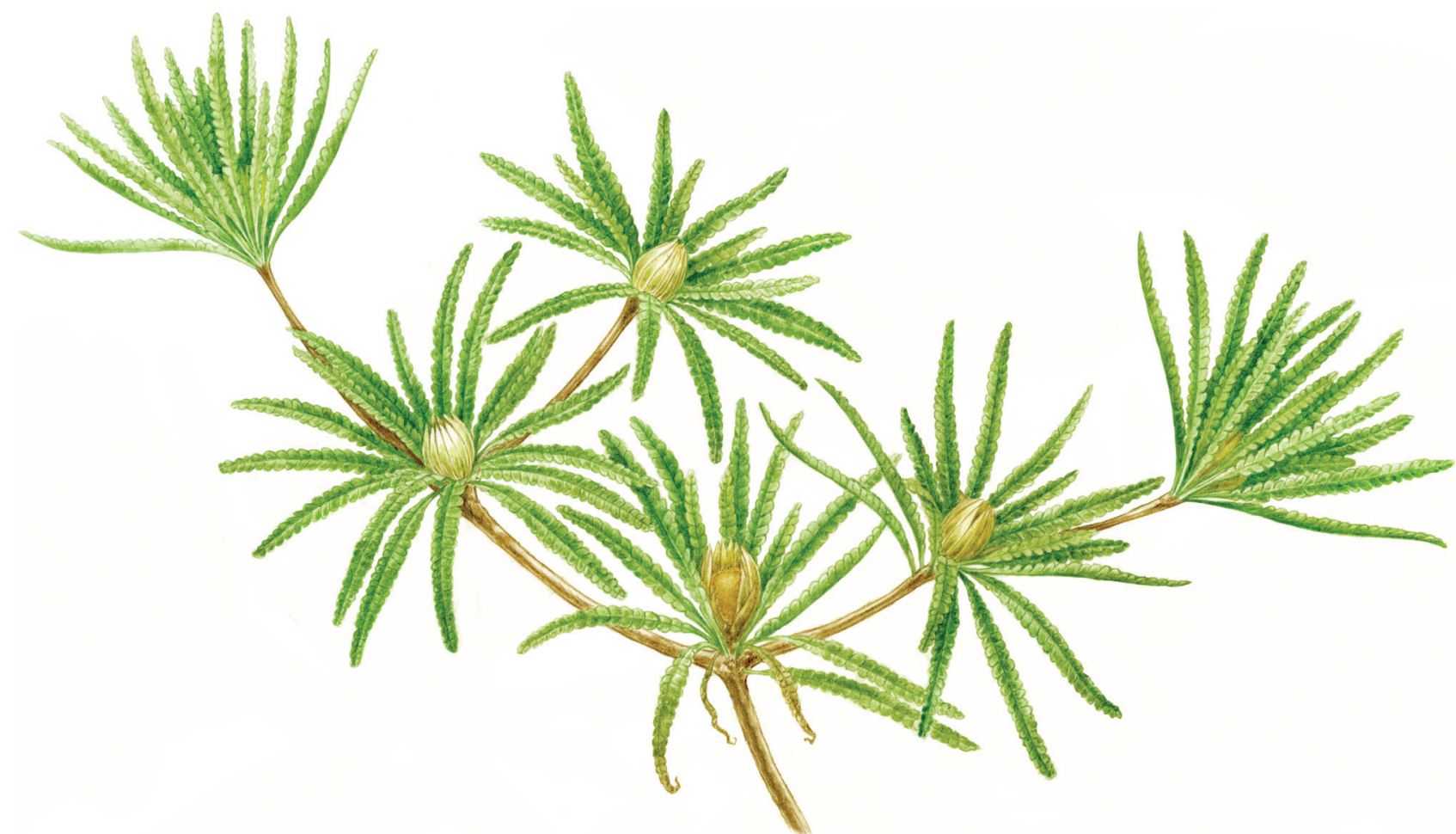

Figure 22 Restoration of Wielandiella angustifolia, a plant very closely related to Wielandiella villosa, depicting the characteristic divaricate architecture of the plant. Drawing by Pollyanna von Knorring, Swedish Museum of Natural History, Stockholm, Sweden. Illustration modified from Pott (2014)

Another species with similar plant architecture is Baikalophyllum lobatum E. Bugdaeva, recently described from the Lower Cretaceous of Liaoning, Inner Mongolia (China) and Transbaikalia (Russian Federation), by Pott et al. (2012a). The authors refrained from a definite assignment to any cycadophyte group, because the peculiar shape and venation of the leaves is intermediate between different groups, and epidermal anatomy, which is a good indicator of, e.g., bennettitalean, cycadalean or nilssonialean affinities (e.g., Pott \& McLoughlin 2009), is only poorly known in the described fossils. Baikalophyllum lobatum differs in its plant architecture from the sympodial dichasial architecture of Wielandiella by the branching pattern that is only superficially similar to Wielandiella, because the main axis continues its growth and is not terminated by a reproductive structure; the divaricate branching of the axis is, consequently, retaining the daughter branches subordinate (Pott \& McLoughlin 2014). Pott et al. (2012a) argued for an affiliation of Baikalophyllum E. Bugdaeva with the Nilssonial Nilssoniocladus-complex based on foliar morphology, the limited epidermal features available and branch architecture (long shoot/short shoot architecture).

\section{Divaricate growth habit as indicator of ecological preferences}

In an elaborate study, Pott \& McLoughlin (2014) examined the peculiar plant architecture of Wielandiella, which has been reconstructed as small-leafed shrubs or low-growing trees with densely interlaced stems bifurcating or trifurcating at broad angles (Fig. 22; Nathorst 1888, Pott 2014, Pott \& McLoughlin 2014, this study), and recognised the divaricating growth form (Kelly 1994, McQueen 2000).
Pott \& McLoughlin (2014) evaluated the concepts, which botanists generally attribute to the benefits of a divaricating habit amongst modern plants, with respect to the ecological pressures known to have been experienced by Wielandiella in the Mesozoic. The hypotheses suggest that this habit evolved (1) to protect foliage and the reproductive structures from browsing by large mammals and tetrapods, or large flightless birds, (2) as a response to a dry, windy or frosty climate, or (3) to optimise foliar light harvesting (see McQueen [2000] and Pott \& McLoughlin [2014] for details and further references).

Little has been inferred about the ecological preferences of Williamsoniaceae despite Wielandiella having been restored as early as 1888 (Pott 2014). Wielandiella encompasses specialised shrubs that are regarded to have thrived in swampy settings but also potentially extended to other lowland habitats, especially where conditions of physiological drought prevailed. In their evaluation, Pott \& McLouchlin (2014) deployed a novel structural and ecological comparison with an extant, although phylogenetically unrelated analogue, viz. members of the Banksiinae (Proteaceae). The authors concluded that two of the hypotheses are potentially applicable to Wielandiella and the Williamsoniaceae.

Wielandiella villosa has been interpreted to have thrived under conditions that, in modern vegetation, are considered to favour the development of divaricate plant growth forms (Pott \& McLoughlin 2014). In addition, the fauna of the Daohugou Biota (Tiaojishan Formation) is dominated by pterosaurs, feathered dinosaurs and primitive bird-like animals (e.g., Sullivan et al. 2014), including Tianyulong confuciusi X.T. Zheng, H.L. You, X. Xu et Z.M. Dong, a species classified as heterodontosaurid ornithischian. Tianyulong confuciusi 
is considered to be herbivorous or potentially omnivorous (Zheng et al. 2009) and thus might be a potential candidate to have fed on bennettites in the Daohugou assemblage (Pott et al. 2012b, Pott \& McLoughlin 2014). The foliage and reproductive organs of these medium-sized shrubs (i.e. $70-100 \mathrm{~cm}$ in height) would have been of suitable size for Tianyulong confuciusi to browse, potentially stimulating a divaricate growth form in Wielandiella villosa.

Although defence against browsing tetrapods cannot be excluded as a selective pressure promoting a divaricate architecture, Pott \& McLoughlin (2014) noted that many of the anatomical and morphological features of Wielandiella appear to represent responses to local environmental conditions, and regarded members of the Banksiinae (Proteaceae) that have adapted to open vegetation communities on nutrient-deficient soils as structural and ecological analogues of Mesozoic Williamsoniaceae.

This is also reflected in the interpretation of the plant architectural model displayed in Wielandiella by, e.g., Hallé et al. (1978), which conforms to Leeuwenberg's model, the strategy of which is evaluated as "common in species of secondary vegetation and disturbed areas both in the tropics and in temperate regions, i.e. in biotopes fairly rich in climatic diversity but poor in competing species" (Hallé et al. 1978 , p. 153)

Wielandiella is regarded to have grown in lowland settings adjacent to the shores of large but shallow, marine embayments or lakes poor in nutrients, in meandering river floodplains within deltaic or coastal plain settings, all of which can be interpreted as types of disturbed areas (Pott 2014, Pott \& McLoughlin 2014). The shrub-like plants achieved heights of one to three metres and mostly overtopped adjacent vegetation by at least half of their size or grew in monotypic stands, significantly reducing competition with other species.

The ecological pressures promoting indumentum development and the protruding hairs (trichomes) on the leaves of Wielandiella villosa, however, have been interpreted by Pott et al. (2012b) as predominantly an adaptation for passive defence against herbivores rather than xeromorphic features. Bristle-like hairs on leaves as displayed by Wielandiella villosa appear to be unique amongst bennettitaleans suggesting that these structures were adaptations to particular environmental parameters (protection against herbivore damage or extreme physical variables) in the Middle Jurassic Daohugou ecosystem. Hair cover in plants has evolved widely to decrease moisture loss under both arid and windy conditions (true xeromorphy; Fahn \& Cutler 1992) and under conditions of physiological drought experienced by plants growing in low nutrient substrates (Fahn \& Cutler 1992). A whitish coloration of the hairs may also reflect solar radiation between 400 and $3000 \mathrm{~nm}$ from the leaf surface (Fahn \& Cutler 1992). Windy conditions may stimulate the production of long and stiff hairs on exposed leaf surfaces.
The lack of other plants with an indumentum in the fossil assemblage though detracts from interpreting the hairs as a general response to xeromorphy. The Daohugou Biota has preliminarily been characterised as indicating a warm-temperate and humid setting (Mi et al. 1996, Tan \& Ren 2002, Wang et al. 2006), but this interpretation of its depositional setting and environment is not universally accepted and currently under revision. Most other possible functions for the hairs in Wielandiella villosa as defences against physical environmental variables (e.g., protection from ultraviolet radiation, salt, dust and volcanic ash, as hydrophobic structures and as devices for the collection of atmospheric moisture) can be eliminated on the basis of the special arrangement and restricted occurrence of the trichomes on the abaxial leaf surface, the biota's lowland depositional setting or the absence of similar adaptations in other plants within the assemblage.

\section{CONCLUSIONS}

The newly discovered fossils presented here necessitated the re-assignment of Anomozamites villosus, previously known from disarticulated foliage only, to Wielandiella based on the peculiar architecture of the plant. The fossils also distinctly expand our knowledge of the habit and the structure of Wielandiella plants. The plants are interpreted to encompass specialised shrubs thriving in swampy settings or extending to other lowland habitats, especially where conditions of physiological drought prevailed. Such conditions are, in modern vegetation, considered to favour the development of divaricate plant growth forms. The medium-sized shrubs would have been of suitable size for ground-based animals to browse foliage and reproductive organs that may also have stimulated a divaricate growth form. Indumentum development and the protruding hairs (trichomes) on the leaves are interpreted as predominantly an adaptation for passive defence against herbivores rather than xeromorphic features. The presented study significantly adds to ongoing investigations currently conducted to exploit and unravel the biota's depositional setting to reconstruct plant life, habitats or plant-animal interactions in the Daohugou ecosystem.

\section{ACKNOWLEDGEMENT}

The authors wish to thank Zhang Xiaomei, Shandong Tianyu Museum of Natural History, Pingyi, for excellent care and assistance during the visits of CP to Pingyi. Manja Hethke, Berlin, Germany, is thanked for fruitful discussions on the ecology and depositional setting of the Daohugou Biota. Tim Topper and Steve McLoughlin, Swedish Museum of Natural History, Stockholm, Sweden, are acknowledged for proof-reading of the English language. CP acknowledges funding from the Swedish Research Council (Vetenskapsrådet), Stockholm, Sweden, under grant number C0437501. WXL and ZXT acknowledge funding by the National Natural Science foundation of China (41372014, 41472023). 


\section{LITERATURE CITED}

Chang, M., P. Chen, Y. Wang, Y. Wang \& D. Miao 2003. The Jehol Biota. The emergence of feathered dinosaurs, beaked birds and flowering plants. Scientific \& Technical Publishers, Shanghai, China, 208 pp.

Chen, W., Q. Ji, D. Liu, Y. Zhang, B. Song \& X. Liu 2004. Isotope geochronology of the fossil-bearing beds in the Daohugou area, Ningcheng, Inner Mongolia. Geological Bulletin of China 23:1165-1169 (in Chinese with English abstract).

Crane, P.R. 1985. Phylogenetic analysis of seed plants and the origin of angiosperms. Annals of the Missouri Botanical Garden 72:716-793.

Fahn, A. \& D.F. Cutler 1992. Xérophytes. Gebr. Borntraeger, Stuttgart, X+176 pp.

Fiore, M. 1935. Presenza della Wielandiella angustifolia Nath. nel lias veronese (Rovere di Velo). Atti della Accademia Nazionale dei Lincei, Rendiconti, Classe di Scienze Fisiche, Matematiche e Naturali 22:467-469.

Gao, K. \& D. Ren 2006. Radiometric dating of ignimbrite from Inner Mongolia provides no indication of a postMiddle Jurassic age for the Daohugou Beds. Acta Geologica Sinica 80:42-45.

Gao, T., D. Ren \& C. Shih 2009. Abrotoxyela gen. nov. (Insecta, Hymenoptera, Xyelidae) from the Middle Jurassic of Inner Mongolia, China. Zootaxa 2094:52-59.

Hallé, F., R.A.A. Oldeman \& P.B. Tomlinson 1978. Tropical trees and forests. Springer, Berlin, XVII+441 pp.

Harris, T.M. 1932. The fossil flora of Scoresby Sound East Greenland, Part 3: Caytoniales and Bennettitales. Meddelelser om Gronland 85:1-133.

Harris, T.M. 1969. The Yorkshire Jurassic flora. III. Bennettitales. Trustees of the British Museum (Natural History), London, VI+186 pp.

He, H., X. Wang, Z. Zhou, R. Zhu, F. Jin, F. Wang, X. Ding \& A. Boven 2004. ${ }^{40} \mathrm{Ar} /{ }^{39} \mathrm{Ar}$ dating of ignimbrite from Inner Mongolia, northeastern China, indicates a postMiddle Jurassic age for the overlying Daohugou Bed. Geophysical Research Letters 31:L20609.

Huang, D., A. Nel, Y. Shen, P.A. Selden \& Q. Lin 2006. Discussions on the age of the Daohugou fauna - evidence from invertebrates. Progress in Natural Science 16:309-312.

Ji, Q., W. Chen, W. Wang, X. Jin, J. Zhang, Y. Liu, H. Zhang, P. Yao, S. Ji, C. Yuan, Y. Zhang \& H. You 2004. Mesozoic Jehol biota from western Liaoning. Geological Publishing House, Beijing, China, 375 pp. (in Chinese).

Kelly, D. 1994. Towards a numerical definition for divaricate (interlaced small-leaved) shrubs. New Zealand Journal of Botany 32:509-518.

Kimura, T., T. Ohana, L.M. Zhao \& B.Y. Geng 1994. Pankuangia haifanggouensis gen. et sp. nov., a fossil plant with unknown affinity from the Middle Jurassic Haifanggou Formation, Western Liaoning, Northeast China. Bulletin of the Kilakyushu Museum of Natural History 13:255-261.

Kryshtofovich, A. \& V. Prynada 1932. Contribution to the Mesozoic Flora of the Ussuriland. Izvestiya V sesoynznogo Geologo-Razvedochnogo Ob'edineniya 51(22):363-374 (in Russian). [Криштофович А.Н., ПринаАа В.А. 1932. Материалы к мезозойской флоре Уссурийского края // Известия Всесоюзного геолого-разведочного объединения. Т. 51, вып. 22. С. 363-374].

Liu, Y., Y. Liu, S. Ji \& Z. Yang 2006. U-Pb zircon age for the Daohugou Biota at Ningcheng of Inner Mongolia and comments on related issues. Chinese Science Bulletin 51: 2634-2644.

Lundblad, A.B. 1950. Studies in the Rhaeto-Liassic floras of
Sweden. I. Pteridophyta, Pteridospermae and Cycadophyta from the mining district of NW Scania. Kungliga Svenska Vetenskapsakadiens Handlingar, Fjärde Serien 1: 1-82.

McQueen, D.R. 2000. Divaricating shrubs in Patagonia and New Zealand. New Zealand Journal of Ecology 24:69-80.

Mi, J., C. Sun, Y. Sun, S. Cui \& Y. Ai 1996. Early-Middle Jurassic phytoecology and coal-accumulating environments in northern Hebei and western Liaoning. Geological Publishing House, Beijing, 169 pp.

Nathorst, A.G. 1880. Några anmärkningar om Williamsonia Carruthers. Öfversikt af Kongliga Vetenskaps-Akademiens Förhandlingar 9:33-52.

Nathorst, A.G. 1888. Nya anmärkningar om Williamsonia. Öfversikt af Kongliga Vetenskaps-Akademiens Förhandlingar 6: 359-365.

Nathorst, A.G. 1909. Paläobotanische Mitteilungen 8. Über Williamsonia, Wielandia, Cycadocephalus und Weltrichia. Kungliga Svenska Vetenskapsakadiens Handlingar 45:3-37.

Nathorst, A.G. 1910. Erratum. Cover slip to Nathorst, A.G. 1909. Paläobotanische Mitteilungen 8, dated 07.01.1910.

Pott, C. 2014. A revision of Wielandiella angustifolia - a shrubsized bennettite from the Rhaetian-Hettangian of Scania, Sweden, and Jameson Land, Greenland. International Journal of Plant Sciences 175:467-499.

Pott, C., M. Krings, H. Kerp \& E.M. Friis 2010. Reconstruction of a bennettitalean flower from the Carnian (Upper Triassic) of Lunz, Lower Austria. Review of Palaeobotany and Palynology 159:94-111.

Pott, C. \& S. McLoughlin 2009. Bennettitalean foliage from the Rhaetian-Bajocian (latest Triassic-Middle Jurassic) floras of Scania, southern Sweden. Review of Palaeobotany and Palynology 158:117-166.

Pott, C. \& S. McLoughlin 2014. Divaricate growth habit in Williamsoniaceae: unravelling the ecology of a key Mesozoic plant group. Palaeobiodiversity and Palaeoenvironments 94: 307-325.

Pott, C., S. McLoughlin, A. Lindström, S.Q. Wu \& E.M. Friis 2012a. Baikalophyllum lobatum and Rehezamites anisolobus: two seed plants with "cycadophyte" foliage from the Early Cretaceous of eastern Asia. International Journal of Plant Sciences 173:192-208.

Pott, C., S. McLoughlin, S.Q. Wu \& E.M. Friis 2012b. Trichomes on the leaves of Anomozamites villosus sp. nov. (Bennettitales) from the Daohugou beds (Middle Jurassic), Inner Mongolia, China: mechanical defense against herbivorous arthropods? Review of Palaeobotany and Palyno$\log y$ 169:48-60

Ren, D., K. Gao, Z. Guo, S. Ji, J. Tan \& Z. Song 2002. Stratigraphic division of the Jurassic in the Daohugou area, Ningcheng, Inner Mongolia. Geological Bulletin of China 21: 584-591 (in Chinese with English abstract).

Shen, Y., P. Chen \& D. Huang 2003. Age of fossil conchostracans from Daohugou of Ningcheng, Inner Mongolia. Journal of Stratigrapby 27:311-313 (in Chinese with English abstract).

Sullivan, C., Y. Wang, D.E. Hone, Y. Wang, X. Xua \& F. Zhan 2014. The vertebrates of the Jurassic Daohugou Biota of northeastern China. Journal of Vertebrate Palaeontology 34: 243-280.

Tan, J. \& D. Ren 2002. Palaeoecology of insect community from Middle Jurassic Jiulongshan Formation in Nincheng County, Inner Mongolia, China. Acta Zootaxonomica Sinica 27:428-434.

Wang, X., Z. Zhou, H. He, F. Jin, Y. Wang, J. Zhang, Y. Wang, X. Xu \& F. Zhang 2005. Stratigraphy and age of the Daohugou Bed in Ningcheng, Inner Mongolia. Chinese Science 
Pott et al.

Bulletin 50:2369-2376.

Wang, Y., S. Ken, W. Zhang \& S. Zheng 2006. Biodiversity and palaeoclimate of the Middle Jurassic floras from the Tiaojishan Formation in western Liaoning, China. Progress in Natural Science 16:222-230.

Zhang, H., M. Wang \& X. Liu 2008. Constraints on the upper boundary age of the Tiaojishan Formation volcanic rocks in West Liaoning-North Hebei by LA-ICP-MS dat- ing. Chinese Science Bulletin 53:3574-3584.

Zheng, S., L. Zhang \& E. Gong 2003. A discovery of Anomozamites with reproductive organs. Acta Botanica Sinica 45:667-672.

Zheng, X.T., H.L. You, X. Xu \& Z.M. Dong 2009. An early Cretaceous heterodontosaurid dinosaur with filamentous integumentary structures. Nature 458:333-336. 